\title{
One Century of Science: The Jesuit Journal Brotéria (1902-2002)
}

\author{
Francisco Malta Romeiras and Henrique Leitão
}

\section{Introduction}

\section{The Jesuits and the History of Science}

For historians of science, one of the most distinctive features of the Society of Jesus was its dedication to science and scientific education, especially when compared with other religious orders. The Jesuits' contributions to early modern science have been studied extensively and are now widely known, lending further credence to George Sarton's (1884-1956) dictum that “one cannot study the history of mathematics in the sixteenth and seventeenth centuries without coming across Jesuits at every corner."1 Fifty years later, in his book on the history of electricity in the seventeenth and eighteenth centuries, John Heilbron (1934-) echoed this assertion by stating that "the single most important contributor to the support to the study of physics in the seventeenth century was the Catholic Church and, within it, the Society of Jesus."2 Today, it is clear that Heilbron and Sarton's statements can be extended to other scientific subjects, especially those connected to the mathematical and physical sciences such as astronomy, seismology, meteorology, and engineering. ${ }^{3}$

1 George Sarton, "Preface to Volume 40: An Appeal for the Republication in Book Form of Father Bosmans' Studies on Belgian Mathematics in the Sixteenth and Seventeenth Centuries," Isis 40 (1949): 3-6, here 3 .

2 John L. Heilbron, Electricity in the 17th and 18th Centuries: A Study of Early Modern Physics (Mineola, NY: Dover, 1999), 2.

3 The literature on Jesuit science is extensive. However, the first attempt at a global synthesis of the scientific history of the Society of Jesus from its foundation to the twentieth century was only published in 2015: Agustín Udías, Jesuit Contribution to Science: A History (London: Springer, 2015). The historiography of the scientific practices of the Jesuits is quite uneven and most historians still pay more attention to the early modern period than to the scientific history of the Society after its restoration in 1814. There are some relevant efforts to study the scientific history of the Society as a whole, such as Udías's book on Jesuit observatories, Searching the Heavens and the Earth: The History of Jesuit Observatories (Dordrecht: Kluwer Academic, 2003), which provides a list of all the observatories since the seventeenth century, but most of the books and papers focus on the history of the Jesuits in the sixteenth, 
Despite abundant historical evidence, the emergence of this portrait of the Jesuits as key contributors to the development of early modern science was not as straightforward as one might suppose. According to the traditional "Whiggish" narrative of the scientific revolution, the Society of Jesus was a conservative, sometimes obscurantist institution, and a major obstacle to the development of modern science. The Jesuits were officially bound to teach Aristotelian Scholastic philosophy, and this requirement came to characterize their educational system. In traditional accounts, this formal adhesion to Aristotle's natural philosophy has been identified as one of the main reasons which supposedly hindered them from adopting new philosophical models and scientific theories, such as Heliocentrism. ${ }^{4}$ However, as the traditional narrative began to be revised, it became clear that this portrait of the Society was much too simplistic. The notion that there had been Protestant novelty and genius as opposed to Catholic backwardness and conservatism in the evolution of early modern science was gradually deconstructed. As a result, historians began to study the Society's scientific contributions in detail, and it is now clear that this religious order was especially relevant not only for the teaching and practice of science in Europe but also for the circulation of scientific knowledge around the world, and especially between Europe, East Asia, and America. $^{5}$

seventeenth, and eighteenth centuries. Among these works, the most relevant are: Jesuit Science and the Republic of Letters, ed. Mordechai Feingold (Cambridge, MA: MIT Press, 2003), The New Science and Jesuit Science: Seventeenth-Century Perspectives, ed. Mordechai Feingold (Dordrecht: Kluwer Academic, 2003); Marcus Hellyer, Catholic Physics: Jesuit Natural Philosophy in Early Modern Germany (Notre Dame, IN: University of Notre Dame Press, 2005); The Jesuits II: Cultures, Sciences and the Arts, 1540-1773, ed. John W. O'Malley, S.J., Gauvin Alexander Bailey, Steven Harris, and T. Frank Kennedy, S.J. (Toronto: Toronto University Press, 2006); The Jesuits: Cultures, Sciences and the Arts, 1540-1773, ed. John W. O'Malley, S.J., Gauvin Alexander Bailey, Steven Harris, and T. Frank Kennedy, S.J. (Toronto: Toronto University Press, 1999); Ugo Baldini, Legem impone subactis: Studi su filosofia e scienza dei gesuiti in Italia, 1540-1632 (Rome: Bulzoni, 1992).

4 Analyzing the historiographical consequences of the traditional narrative of the scientific revolution is not the aim of this chapter. For an overview, see Sheila J. Rabin, "Early Modern Jesuit Science: A Historiographical Essay," Journal of Jesuit Studies 1, no. 1 (2014): 88-104 (doi: 10.1163/22141332-00101006). For modern narratives of the so-called scientific revolution see The Cambridge History of Science, vol. 3: Early Modern Science, ed. Katharine Park and Lorraine Daston (Cambridge: Cambridge University Press, 2006); Steven Shapin, The Scientific Revolution (Chicago: Chicago University Press, 1996); Reappraisals of the Scientific Revolution, ed. David C. Lindberg and Robert S. Westman (Cambridge: Cambridge University Press, 1990).

5 On the circulation of knowledge between Europe and China, see Florence C. Hsia, Sojourners in a Strange Land: Jesuits and Their Scientific Missions in Late Imperial China (Chicago: 
In the history of the Society of Jesus, there were always groups of men devoted to the teaching and practice of science. The creation of scientific courses and scientific academies within their colleges, the commitment to science for missionary purposes, and in some cases the pursuit of high-level scientific practices makes it impossible to understand the scope and influence of this religious order without considering the science some of its members produced. ${ }^{6}$

\section{The Jesuits and the History of Scientific Popularization in Europe}

The "Republic of Letters" that so deeply influenced the intellectual history of seventeenth- and eighteenth-century Europe was above all a transnational network of communication between members of the European literati. During this period, the increasing amount of academic correspondence, the creation of well-known salons and academies, and the foundation of the first scientific journals played a crucial role in the circulation of knowledge, especially in Europe and North America. ${ }^{7}$

The French Jesuits were aware of the importance of participating in this metaphorical and learned nation, and followed the scientific tradition of the previous centuries by launching the Society's first learned periodical. Published in Trévoux and officially entitled Mémoires pour l'histoire des sciences et des beaux arts (1701-67), it later became more commonly known as the Journal de Trévoux. ${ }^{8}$ The journal was founded with the support of Louis-Auguste de Bourbon (1670-1736), the duke of Maine and legitimized son of the French

University of Chicago Press, 2009); Liam M. Brockey, Journey to the East: The Jesuit Mission to China, 1572-1724 (Cambridge, MA: Harvard University Press, 2007); Luís Saraiva and Catherine Jami, eds., History of Mathematical Sciences: Portugal and the East Asia, III-The Jesuits, the Padroado and East Asian Science (1552-1773) (Singapore: World Scientific, 2008). On the scientific activities of the Jesuits in America see Andrés I. Prieto, Missionary Scientists: Jesuit Science in Spanish South America, 1570-1810 (Nashville, TN: Vanderbilt University Press, 2011).

6 The expression "scientist" can be anachronistic when applied to scientific practitioners in the sixteenth and seventeenth centuries. In this chapter, we use it as a general category to refer to mathematicians, astronomers, natural philosophers, and other classical early modern scientific practitioners.

7 Among the most renowned initiatives of the Republic of Letters are the foundation of the Académie Française (1635), the Royal Society (166o), and the Académie des Sciences (1666), and the publication of two learned journals: the Journal des sçavans (first printed in January 1665) and the Philosophical Transactions (first printed in March 1665).

8 On the history of the Journal de Trévoux see Marie-Hélène Froeschlé-Chopard and Michel Froeschlé, “'Sciences et Arts' dans les Mémoires de Trévoux (1701-1762)," Revue d'histoire moderne et contemporaine 48, no. 1 (2001): 30-49; Jean Laponce, "The Jesuits and Science in Eighteenth-Century France: An Analysis of Scientific Writings in the Journal of Trévoux" 
king Louis XIV (1638-1715), and was especially relevant not only for the scientific history of the Society of Jesus but also for its role in disseminating modern scientific research to a broad audience.

Its foundation at the beginning of the eighteenth century was associated with two central religious affairs in this period: the controversies surrounding the expansion of Jansenism and the revocation of the Edict of Nantes in 1685, which led to the expatriation of French Calvinists. With the publication of a periodical such as the Journal de Trévoux, the French Jesuits had found an efficient vehicle to put forth their points of view and participate in those religious quarrels. ${ }^{9}$ Yet while the Journal de Trévoux is known for its role in the defense of Cartesianism in France and for its articles on physics and mathematics, it was in fact a very eclectic periodical. The wide array of subjects it covered, including theology, philosophy, history, law, economics, natural history, astronomy, fine arts, medicine, and agriculture, and the high-quality of its scholarship, distinguished it, together with the Journal des Sçavans, as one of the most important learned journals to be published in France during the Enlightenment. ${ }^{10}$

In 1750, following the success of the Journal de Trévoux, the Italian Jesuit Francesco Antonio Zaccaria (1714-95) founded an encyclopedic journal entitled Storia letteraria d'Italia. Each one of its volumes, which were published between $175^{\circ}$ and 1759 , contained a section exclusively dedicated to science with articles commenting on modern books and scientific topics in numerous fields such as mathematics, physics, chemistry, medicine, and astronomy. Apart from describing scientific novelties, which constituted the core of the scientific section, the authors also described their astronomical observations, such as the observation of solar eclipses, lunar eclipses, and the transit of Mercury. ${ }^{11}$ Yet Storia letteraria d'Italia would have a short and controversial life. As Zaccaria and his collaborators became increasingly virulent but "failed to silence their most vociferous critics," the "enthusiasm of Zaccaria's ecclesiastical superiors" diminished, leading the Jesuit superior general Ignazio Visconti

(MSc. diss., University of British Columbia, 1990). On the involvement of the Jesuits in the Republic of Letters see also Feingold, Jesuit Science and the Republic of Letters.

9 Laponce, "Jesuits and Science in Eighteenth-Century France," 23-24.

10 For a thematic index of the articles published in the Journal de Trévoux, see Carlos Sommervogel S.J., Table méthodique des Mémoires de Trévoux (1701-1775) (Paris: Imprimerie de E. Donnaud, 1864-65).

11 Brendan Dooley, "The Storia letteraria d'Italia and the Rehabilitation of Jesuit Science," in Feingold, Jesuit Science and the Republic of Letters, 433-73. Storia letteraria d'Italia described the observations of the solar eclipses of January 8 and June 19, 1750, the lunar eclipse of June 8, 1751, and the transit of Mercury on May 5,1753 . 
(1682-1755) to intervene and institute pre-publication censorship. When the controversies surrounding its articles continued to linger on, Superior General Lorenzo Ricci (1703-75) requested its suspension "for the better interest of the order" and, despite its commercial success and the efforts of Francesco III (1698-1780), duke of Modena, to secure its subsistence, publication of the Storia letteraria d'Italia was finally suspended in $1759 .^{12}$

In the nineteenth century, the Jesuits revived their determination to edit learned periodicals directed at a broad audience, with La Civiltà Cattolica being the first journal to appear after the restoration of the Society in 1814. Founded in Naples by Carlo Maria Curci, S.J. (1810-91) in April 1850, the journal's first issue stated that its main purpose was to provide a careful and logical explanation of Catholic doctrine and moral principles. ${ }^{13}$ From 1866 onwards, after the foundation of a house of writers exclusively committed to its publication, $\mathrm{La}$ Civiltà Cattolica fell under the jurisdiction of the Roman Curia and of Pius IX (r.1846-78), who instructed the Jesuits to dedicate themselves to refuting the heterodox doctrines circulating in the press. The authors of La Civiltà Cattolica consequently participated in the main political, philosophical, theological, and scientific quarrels of the day, thus establishing the journal as one of the most important cultural Italian periodicals. ${ }^{14}$

In $185^{6}$, only six years after the foundation of La Civiltà Cattolica, the Jesuits founded the cultural magazine Études religieuses, philosophiques, historiques et littéraires in Paris. As a periodical aimed at a wide audience, Études, as it came to be known, published articles on subjects such as architecture, archeology, history, geography, demography, education, sociology, law, politics, philosophy, and theology. It also addressed controversial topics of especial interest to the defense of the Catholic faith, such as freemasonry, positivism, Protestantism, and Jansenism..$^{15}$ Following the example of the Journal de Trévoux and of the Storia letteraria d'Italia, Études also published popular scientific articles on

12 Dooley, "Storia letteraria d'Italia and the Rehabilitation of Jesuit Science," 459.

13 "Il giornalismo moderno ed il nostro programma," La Civiltà Cattolica 1 (1850): 5-24.

14 On the history of La Civiltà Cattolica from $185^{0}$ to 1999, see Giuseppe de Rosa, S.J., La Civiltà Cattolica: 150 anni al servizio della Chiesa, 1850-1999 (Rome: La Civiltà Cattolica, 1999).

15 For the reconstruction of the main subjects covered by the journal Études from 1856 to 1924, see the following indexes: Études religieuses, philosophiques, historiques et littéraires publiée par des pères de la Compagnie de Jésus. Table générale des vingt-cinq premières années (1856-1880) (Paris: Victor Retaux \& Fils, Éditeurs, c.1880); Études publiées par des pères de la Compagnie de Jésus. Table générale des années 1880 a 1900 (Paris: Victor Retaux, Librairie-Éditeur, c.190o); Études. Tables des années 1911-1924 (Paris: Bureau des Études, 1926). 
botany, physiology, physics, chemistry, astronomy, meteorology, medicine, and hygiene, and covered polemical issues in the history of science such as Darwinism and the Galileo affair. ${ }^{16}$ However, the period in which the French Jesuits most actively engaged in popularizing scientific research only corresponds to the first quarter of the history of Études (1856-80), as the journal's focus on scientific themes gradually diminished in the years that followed.

The success of La Civiltà Cattolica and Études inspired the foundation of other Jesuit cultural magazines such as The Month (England, 1864), Stimmen der Zeit (Germany, 1865), Razón y fé (Spain, 1901), and America (United States, 1909), to name but a few. With the publication of Razón y fé, as the title itself suggested, the Jesuits aspired to participate in the controversies related to the so-called conflict between science and faith, and thus contribute to the discussion and acceptance of the compatibilist thesis. In its opening issue, they justified the publication of the new journal by arguing that the "public tribune of the press" was the best stage to dispute the "clamor of false science, untruthful philosophy and corrupting literature," which had been undermining Catholic doctrine. ${ }^{17}$ For the editors, the foundation of Razón y fé was firmly rooted in the ideological and political struggles of Pius VII (r.180o-23), Leo XII (r.1823-29), Gregory XVI (r.1831-46), and Pius IX against modernism, as well as addressing the need to foster the development of a Catholic culture. In one editorial contesting the views of anticlerical critics, they recalled the encyclical Immortale Dei (1885), in which Leo XIII (r.1878-1903) openly declared the church's support of science: "whatsoever spreads the range of knowledge will always be willingly and even joyfully welcomed by the Church. She will always encourage and promote, as she does in other branches of knowledge, all study occupied with the investigation of nature."18 While describing the publication of the

16 From 1856 and 1880 , the following articles criticized Darwinism and commented on the Galileo affair: v. Becker, "Un duel darwiniste (Haeckel et His)," Études 21 (1877): 672-88; J. de Bonniot, "Darwinisme et logique," Études 16(1872): 423-43; I. Carbonnelle, "Le darwinisme, théorie et objections," Études 14 (1869): 472-82; E. Desjardins, "M. Mézières et le procès de Galilée," Études 21 (1877): 273-81; A. de Gabriac, "Galilée devant la science, la religion et la littérature," Études 12 (1867): 528-47.

17 "Y como contra las afirmaciones y negaciones católicas se ha levantado hace tiempo el clamoreo de la falsa ciencia, la mentida filosofía y la literatura corruptora, de ahí también que se haya impuesto la necesidad de combatirlas, no sólo desde la cátedra del Espíritu Santo ó desde las cátedras del público magisterio, sino desde la pública tribuna de la prensa”: “À los lectores," Razón y fé I (1901): 1-5, here 2.

18 Leo XIII, Immortale Dei (Rome: November 1, 1855). English translation available from http://w2.vatican.va/content/leo-xiii/en/encyclicals. 
journal as part of a broader apostolic mission, the editorial's authors also resorted to the warlike metaphors of Ignatius of Loyola $(c .1491-1556)$ and presented themselves as the last "soldiers" of an "army" that always fought for the greater glory of God. ${ }^{19}$

The journal sought to publish scientific articles that would appeal to specialists and non-specialists alike. During the initial years of its publication, Razón y fé documented some of the Society's scientific activities in Spain, with articles describing the astronomical and meteorological observatory in Granada, for instance, or one which provided an account of a Jesuit naturalist who was traveling through the region of Galicia identifying and classifying novel botanical species. ${ }^{20}$ It is clear from these articles that the Spanish Jesuits were aiming to present themselves not only as defenders of the compatibility of faith and science but also as active and modern practitioners of sciences such as astronomy, meteorology, and natural history.

While they were published in very different historical, political, and geographical contexts, the journals mentioned above served a common purpose: to display the willingness and ability of the Jesuits to participate in the major philosophical, theological, political, and scientific debates of their time. Moreover, as well as the voice of the Society of Jesus, the journals also served to convey the unofficial voice of the Holy See.

19 "Ese es su santo y seña, que únicamente no entienden ni creen los enemigos de la Iglesia, de la patria y de la verdad. Pero es un santo y seña que entienden los buenos católicos. A tiempo llegamos; pues si no es esta la hora de la victoria, es, según todos los prenuncios, la hora del sacrificio. Y si no nos cabe la dicha de ver el triunfo completo de la verdad, de la Iglesia y de la patria, nos cabrá al menos, en compañía de los demás combatientes, la inmerecida gloria de morir por la Iglesia, por la patria y por la verdad, que son inmortales": "A los lectores," 4-5.

20 On the observatory of Granada, see Juan Granero, S.J., "El Observatorio astronómico, geodinámico y meteorológico de Granada," Razóny fé 3 (1902): 222-25; Granero, “Observatorio de Granada," Razón y fé 3 (1902): 512-20; Ramón Martínez, S.J., “Observatorio de Granada Sección metereológica," Razón y fé 4 (1902): 478-90; Juan Granero, S.J., "Observatorio de Granada. Sección astronómica," Razón y fé 5 (1903): 339-47. Apart from the textual descriptions, these articles were also accompanied by photographs and illustrations of the scientific instruments. On the journey through Galicia, see Baltasar Merino, S.J., "Viajes de herborización por Galicia," Razón y fé 1 (1901): 95-98; Merino, "Viajes de herborización por Galicia (II)," Razón y fé 2 (1902): 82-89; Merino, "Viajes de herborización por Galicia (III)," Razón y fé 2 (1902): 367-73; Merino, "Viajes de herborización por Galicia (Iv)," Razón y fé 4 (1902): 82-93; and Merino, "Viajes de herborización por Galicia (v)," Razón y fé 5 (1903): 348-6o. 


\section{The Journal Brotéria (1902-2002)}

\section{The Foundation of a Scientific Journal}

In 1902, a group of teachers from the Colégio de São Fiel, a Jesuit college in a small Portuguese town, began to publish a scientific journal, Brotéria, the first Jesuit periodical devoted exclusively to science (Figure 12.1). ${ }^{21}$

Brotéria, which borrowed its name from the prominent Portuguese naturalist Félix Avelar Brotero (1744-1828), was initially intended to disseminate scientific work on botany and zoology by Portuguese naturalists. The journal was established by the Jesuits Joaquim da Silva Tavares (1866-1931), Cândido de Azevedo Mendes (1874-1943), and Carlos Zimmermann (1871-1950), naturalists and teachers of natural science at the Colégio de São Fiel, and aimed to present research concerning the identification and description of novel zoological and botanical species. At that time, this was the main field of research in which the journal's founders were engaged. To justify their scientific program and gain approval to publish Brotéria, the three Jesuit naturalists recalled the famous metaphor of the "Two Books" by stating that the journal's main objective was to increase awareness of their research and to promote science in Portugal, which would in turn contribute to an improved understanding of God's mysteries: ${ }^{22}$

We rejoice in the idea that our contributions, as insignificant as they might be, can disseminate the taste for the natural sciences in our country. The natural world is a vast book, which has many pages to be opened. The name of our grand Creator is written on each of them. When opening these pages, what greater satisfaction could anyone have than unveiling the greatness of God, which is stamped equally on the immensity of the

21 The complete title of this journal in the opening issue was Brotéria-Revista de sciencias naturaes do Collegio de S. Fiel. However, it became known simply as Brotéria. On the scientific history of Brotéria see Francisco Malta Romeiras, "Das ciências naturais à genética: A divulgação científica na revista Brotéria (1902-2002) e o ensino científico da Companhia de Jesus nos séculos XIX e Xx em Portugal" (PhD diss., University of Lisbon, 2014), 173-309; Francisco Malta Romeiras, "The Journal Brotéria (1902-2002): Jesuit Science in the 2oth Century," HoST: Journal for the History of Science and Technology 6 (2012): 100-9; Francisco Malta Romeiras and Henrique Leitão, "Jesuítas e ciência em Portugal. IV—A revista Brotéria-Sciencias naturaes e a sua recepção nacional e internacional," Brotéria 174 (2012): 323-33.

22 For a detailed historical account of the metaphor of the "Two Books," see Olaf Pedersen, The Two Books: Historical Notes on Some Interactions between Natural Science and Theology (Vatican: Vatican Observatory Foundation, 2007). 
world and on the myriad of tiny animals and plants, whose existence only the microscope can uncover? ${ }^{23}$

Despite the apostolic intention behind its creation, Brotéria was conceived as a scientific journal focused on the publication of original botanical and zoological research, not only by Jesuits but also lay scientists. Hence, unlike other contemporary learned periodicals the Society published, Brotéria was not an apologetic magazine with a scientific section, but a strictly scientific journal. Rather than promoting intellectual debates on the compatibility of science and faith, the Portuguese Jesuits sought to present their own scientific accomplishments and thus their direct participation in the development of Portuguese science. Their undeclared objective was to project a public image of the Jesuits as active and competent scientists, something which could not be achieved by producing an apologetic journal.

It is likely that the decision to start publishing Brotéria was made in response to the adverse cultural environment prevailing at the time of the Society's restoration in Portugal. Although a long period had elapsed since the marquis of Pombal's expulsion of the Jesuits in the eighteenth century (1759) and the restoration of the Society of Jesus in the nineteenth century (1858), accusations of obscurantism and scientific conservatism-one of the vectors of Pombal's attack—still haunted the Portuguese Jesuits. ${ }^{24}$

The need to contradict this accusation, together with the increasing importance of science in the late nineteenth century, shaped their new apostolates and initiatives. The Portuguese Jesuits not only had to face contemporary adversaries but also a historical legacy that was seriously tainting their image, and this helps explain why their scientific activities featured so prominently in the journal and their educational and cultural initiatives more broadly. The creation of Broteria was the highpoint of a set of initiatives in the Portuguese Jesuit colleges which included the creation of modern chemistry and physics

23 "Duas palavras de introdução," Brotéria 1 (1902), v; the original reads: "A ideia de concorrermos, por pouco que seja, para propagar o gosto das sciencias naturaes em nossa patria enche-nos de alegria. A natureza é um livro immenso, que tem ainda muitas folhas por abrir. Ora em todas ellas se encontra escrito o nome augusto do Creador. E será acaso pequena satisfacção ao abril-as mostrar nellas a grandeza de Deus, que tanto se estampa na immensidade do mundo, como na extrema pequenez, de myriades de animaes e planas, cuja existencia só o microscopio nos revela?"

24 For a detailed account of the history and relevance of this stubborn accusation see Francisco Malta Romeiras and Henrique Leitão, "The Role of Science in the History of Portuguese Anti-Jesuitism," Journal of Jesuit Studies 2, no. 1 (2015): 77-99 (doi: 10.1163/ 22141332-00201004). 


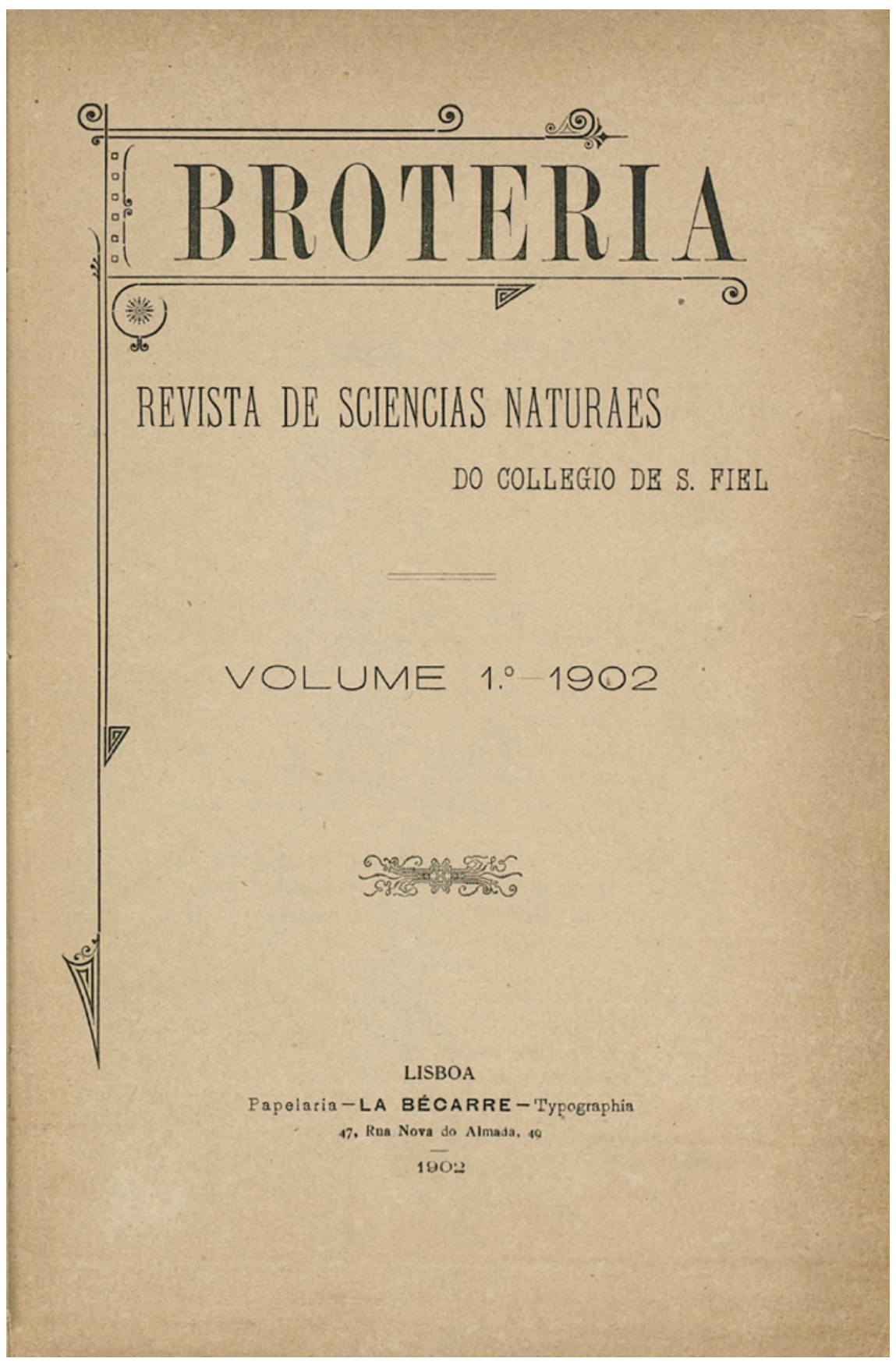

FIGURE 12.1 Cover of the first issue of the Journal Brotéria, October 1902 CREDITS: ARCHIVES OF THE JOURNAL BROTÉRIA 
laboratories, the curation of natural history collections, the promotion of scientific expeditions with students (to observe eclipses or to collect zoological and botanical specimens), the founding of scientific academies, and the promotion of hands-on experimental teaching of the natural sciences. ${ }^{25}$

\section{The First Thirty Years: The Consolidation of a Taxonomical Journal (1902-1931)}

From 1902 to 2002, Brotéria published around 1,300 scientific articles covering a variety of fields including botany, zoology, plant breeding, biochemistry, and molecular genetics. Its initial focus on identifying, describing, and classifying novel species played an important part in the development of the botanical and zoological sciences. The taxonomical work published in its pages described more than two thousand new species of animals and plants, pertaining in most cases to the Portuguese, Spanish, Brazilian, and German fauna and flora, and Brotéria soon caught the attention not only of Portuguese naturalists but also of international taxonomists. The significance of Brotéria as a taxonomical journal is clear not only from the praise the journal received from some of Portugal's most prominent naturalists but also by the inclusion of the species it described in the annual catalogs of international journals such as the American Naturalist, the Journal of Mycology, and the Bulletin of the Torrey Botanical Club, the first American journal devoted to botany. ${ }^{26}$

Following some changes to the editorial structure in 1907, the articles on botany and zoology were published in two separate series: the Botânica and the Zoologia series, ${ }^{27}$ both of which were published until 1931. They shared a common taxonomical program, yet while the articles on botany covered a variety of taxa (diatoms, mosses, fungi, lichens, and phanerogams [i.e., plants that

25 For a detailed description and discussion of the scientific activities developed in the Colégio de São Fiel (1863-1910) and in the Colégio de Campolide (1858-1910), see Romeiras, "Das ciências naturais à genética," 100-49; Francisco Malta Romeiras and Henrique Leitão, "Jesuítas e ciência em Portugal. III. As expedições científicas e as observações dos eclipses solares de 1900 e 1905," Brotéria 174 (2012): 227-37; Francisco Malta Romeiras and Henrique Leitão, "Jesuítas e ciência em Portugal. II. Carlos Zimmermann S.J. e o ensino da microscopia vegetal," Brotéria 174 (2012): 113-25.

26 On the national and international reception of Brotéria, see Francisco Malta Romeiras and Henrique Leitão, "Jesuítas e ciência em Portugal. IV—A revista Brotéria-Sciencias naturaes e a sua recepção nacional e internacional," Brotéria 174 (2012): 323-33.

27 The series Botânica, Zoologia, and Vulgarização científica were published alternately. The series Vulgarização científica was published in January, March, May, July, September, and November; the series Zoologia in February, June, and October; and the series Botânica in April, August, and December. 
produce seeds]), the articles on zoology focused mainly on entomology, thus coinciding with the scientific interests of Silva Tavares and Azevedo Mendes, who were both entomologists.

As well as research on the continental fauna and flora of Portugal, Brotéria's authors also described the fauna and flora overseas, especially in Madeira, Azores, Mozambique, and Angola. The Portuguese Jesuit missions in Mozambique and Angola played an important part in this endeavor as the missionaries were often instructed to collect new specimens of animals and plants and send them to Portugal to be identified, described, and classified. One example of this circulation of knowledge, which emphasizes the important role Brotéria played in identifying new zoological species, involves the correspondence between two Jesuit brothers: João Azevedo Mendes (1883-1940), a missionary in Africa (Angola and Mozambique), and Cândido de Azevedo Mendes, an entomologist specializing in the identification and classification of lepidopterans (i.e., moths and butterflies), during the latter's exile in Salamanca following the republican expulsion of the Portuguese Jesuits in 1910. Although he was not a naturalist, João Azevedo Mendes collected new African specimens of moths and butterflies at the request of his brother, ${ }^{28}$ and hence the correspondence between the two allowed Cândido de Azevedo Mendes to study the entomological fauna of Angola and Mozambique. As in the sixteenth and seventeenth centuries, the communication between members of the Society of Jesus again proved crucial for the circulation of scientific knowledge.

Botanical and zoological knowledge and the specimens themselves were also shared with lay botanists and zoologists as well as Jesuits. The motive for sharing these specimens between the authors whose articles appeared in Brotéria and other scientists was the need to validate hypothetical new botanical or zoological species, especially when the collector was not an expert on that taxon. An interesting example of this was the description of Centaurea luisieri, a previously unknown species of thistle (Figure 12.2), ${ }^{29}$ which had been collected in 1915 by the Jesuit Alphonse Luisier (1872-1957) near Salamanca, and sent to the Portuguese botanist Gonçalo Sampaio (1865-1937) of the University of Oporto.

As neither man was an expert on thistles-Luisier specialized in identifying mosses while Sampaio was an expert in the description of lichens- they asked

28 On the African species described see Cândido Azevedo Mendes, S.J., "Lepidoptera africana I. Ex Zambezia lusitana," Brotéria-Zoologia 10 (1912): 183-91; Cândido Azevedo Mendes, S.J., "Lepidoptera africana II. Ex Angola lusitana," Brotéria-Zoologia 10 (1912): 191-93.

29 Gonçalo Sampaio, “Centaurea luisieri (sp. n.)," Brotéria—Botânica 14 (1916): 104-5. 


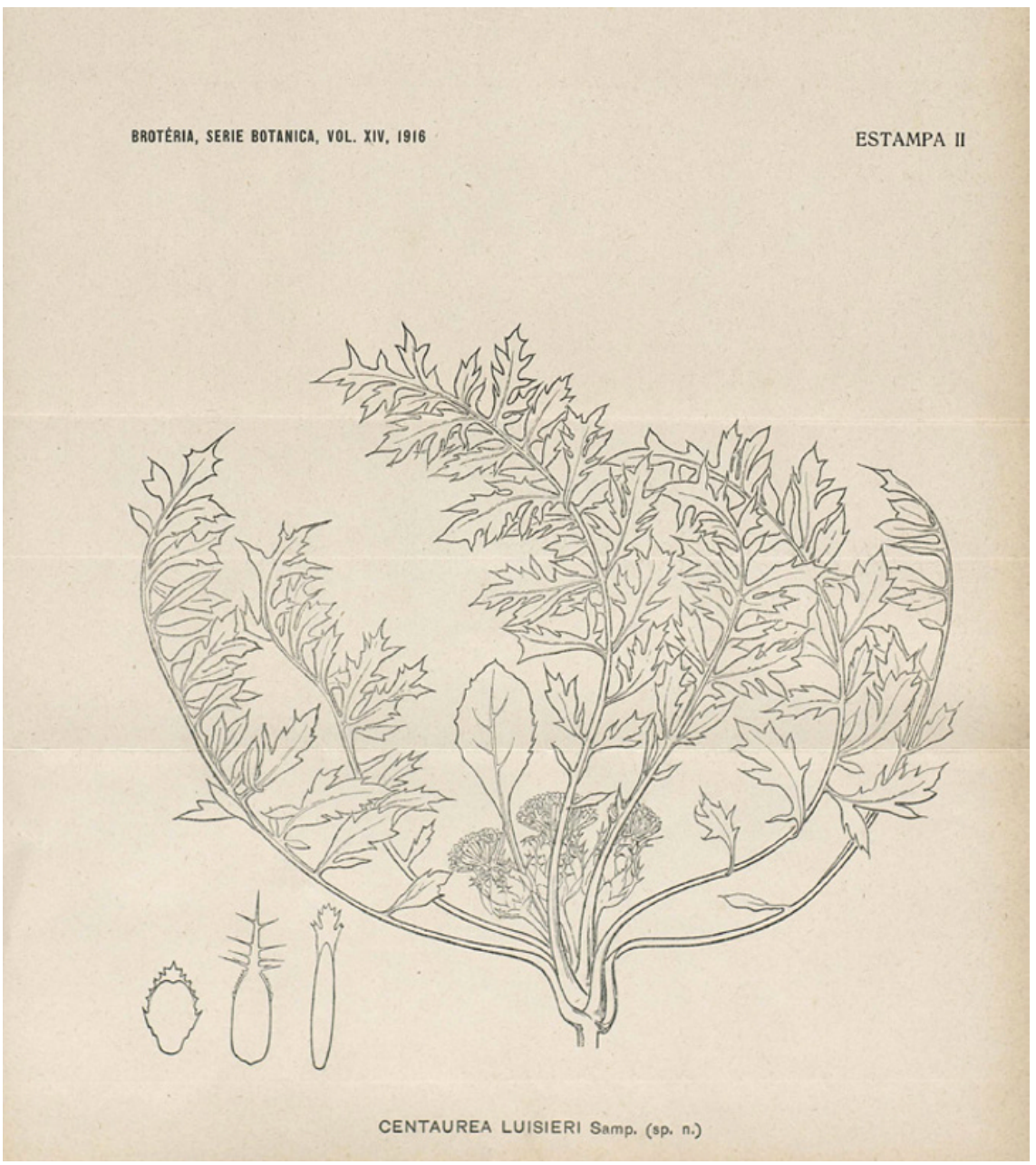

FIGURE 12.2 Centaurea luisieri

ADAPTED FROM BROTÉRIA-BOTÂNICA 14 (1916): STAMP II.

CREDITS: ARCHIVES OF THE JOURNAL BROTÉRIA

another botanist to confirm their discovery. After traveling from Salamanca to Oporto, the thistle sample was consequently sent to Júlio Henriques $\left(183^{8}-\right.$ 1928) in Coimbra, who was one of the most renowned Portuguese botanists of his day. ${ }^{30}$ Upon receiving confirmation from Henriques that it was indeed a

30 Henriques was the founder and director of the taxonomical journal Boletim da Sociedade Broteriana and was also in charge of the museum and botanical garden of the University of Coimbra. 
new species, Sampaio described the discovery in the pages of Brotéria and named it Centaurea luisieri in homage to Father Luisier, who had collected it. ${ }^{31}$

In a period when the networks of scientific correspondence were particularly relevant for the identification, description, and classification of novel species, Brotéria established itself as an international journal of taxonomy with works from renowned Portuguese and foreign botanists and zoologists. ${ }^{32}$ The establishment and maintenance of these networks, which transcended the boundaries of the Society of Jesus, not only contributed to the circulation of knowledge but also to Brotéria's national and international scientific prestige.

\section{Financial Problems and the Foundation of a Popular Scientific \\ Magazine}

Between 1902 and 1906, Brotéria was directed at an academic audience. In this period, the Portuguese Jesuits exchanged their journal with more than one hundred national and international scientific magazines. ${ }^{33}$ This enabled the research published in Brotéria to reach a wide audience, but it also led to significant financial problems. As the journal specialized in identifying and

31 Gonçalo Sampaio, “Centaurea luisieri (sp. n.)," 105. For more examples of the circulation of specimens between the Jesuits and other botanists and zoologists see Romeiras, "Das ciências naturais à genética," $245^{-71}$.

32 The most important authors in Brotéria between 1902 and 1932 can be subdivided according to two mutually non-exclusive criteria: nationality and belonging to the Society of Jesus. According to these criteria, the most relevant authors in this period are: (a) botanists of the Portuguese province of the Society of Jesus: Alphonse Luisier (1872-1957), Camilo Torrend (1875-1961), Carlos Zimmermann (1871-1950), and Joaquim da Silva Tavares (1866-1931); (b) foreign Jesuit botanists: Baltasar Merino (1845-1916), Longino Navás (1858-1938), Johann Rick (1869-1946), Fernando Theissen (1877-1919), and Jaime Pujiula (1869-1958); (c) non-Jesuit Portuguese botanists: José d'Ascenção Guimarães (1862-1922), Gonçalo Sampaio (1865-1937), and Júlio Henriques (1838-1928); (d) nonJesuit foreign botanists: Erwin Baur (1875-1933), Romualdo González Fragoso (1862-1928), Carlos Pau y Español (1857-1937), and Emili Huguet i Serratacó (1871-1951), also known as Huguet del Villar; (e) zoologists of the Portuguese province of the Society of Jesus: Cândido de Azevedo Mendes (1874-1943) and Joaquim da Silva Tavares (1866-1931); (f) foreign Jesuit zoologists Longino Navás (1858-1938); Pelegrín Franganillo-Balboa (1873-1955), Jean-Jacques Kieffer (1857-1925); (g) non-Jesuit Portuguese zoologists: José Maximiano Corrêa de Barros and Carlos França (1877-1926); and (h) non-Jesuit foreign zoologists: Alfredo Corti (1880-1973), Charles Brues (1879-1955), Mario Bezzi (1868-1927), Paul Choffat (1849-1919), and Per Olof Christopher Aurivillius (1843-1928).

33 Instead of just selling Brotéria to their readers, Portuguese Jesuits also interchanged it with other scientific journals. This editorial practice, still common today, allowed them to diffuse their works and it facilitated their access to other modern scientific journals. 
classifying new species of animals and plants, its primary readership was made up of professional botanists and zoologists, and as these scientists directly collaborated with some of the journals that permuted with Brotéria, they could easily access the journal and, more importantly, they could do so for free. ${ }^{34}$ The number of paying non-academic subscribers, on the other hand, was largely insignificant, which meant that the revenue from subscriptions was insufficient for covering the costs of publication. To compensate for the lack of individual subscriptions, in 1907 Silva Tavares restructured Brotéria by dividing it into three separate periodicals: the two scientific series already mentioned, Botânica and Zoologia, and a popular scientific periodical, Vulgarização científica. ${ }^{35}$ Vulgarização científica, which was written entirely in Portuguese, was directed at "less instructed people" and was designed to make a profit and thus cover the expenses of the Zoologia and Botânica series, whose articles, in English, French, German, Spanish, Portuguese, and Latin, were only of interest to professional botanists and zoologists. ${ }^{36}$ The journal published more than $45^{\circ}$ articles on chemistry, physics, agriculture, commerce and industry, medicine and hygiene, seismology, geography, and archaeology between 1907 and 1924, when it ceased publication, and played an important role in disseminating knowledge of these subjects to a non-specialist Portuguese readership.

In 1913, following the success of Vulgarização cientifica, the Spanish Jesuits from the Observatorio del Ebro started to publish Ibérica (1913-36; 1945-2004), a weekly magazine devoted to "general scientific culture."37 The journal's principal objective of making "science accessible to everyone" was encapsulated in its subtitle: "El progreso de las ciencias y de sus aplicaciones." Ibérica went on to become one of the most important popular scientific journals in Spain with its articles on physics and the natural sciences, astronomy, meteorology, seismology,

34 On this, see Romeiras, "Das ciências naturais à genética," 194-202.

35 As the publication of Vulgarização científica was insufficient to secure the publication of Brotéria, the successive editors adopted other strategies which proved to be rather effective, such as the plea for benefactors, the publication of advertisements, and the attraction of public funds from the national agency for science.

36 "Prólogo," Brotéria-Vulgarização científica 6 (1907): 7.

37 Ricard Cicera, S.J., "La ciencia al alcance de todos," Ibérica Spécimen A (1913): 1-5, here 1; the original reads: "La revista semanal que designamos con este nombre Ibérica tiene por fin la cultura general científica, no limitándola a las ciencias astronómicas, aun tomadas en toda su amplitud, sino extendiéndola a todas las ciencias y a un a sus múltiples y casi infinitas aplicaciones." 


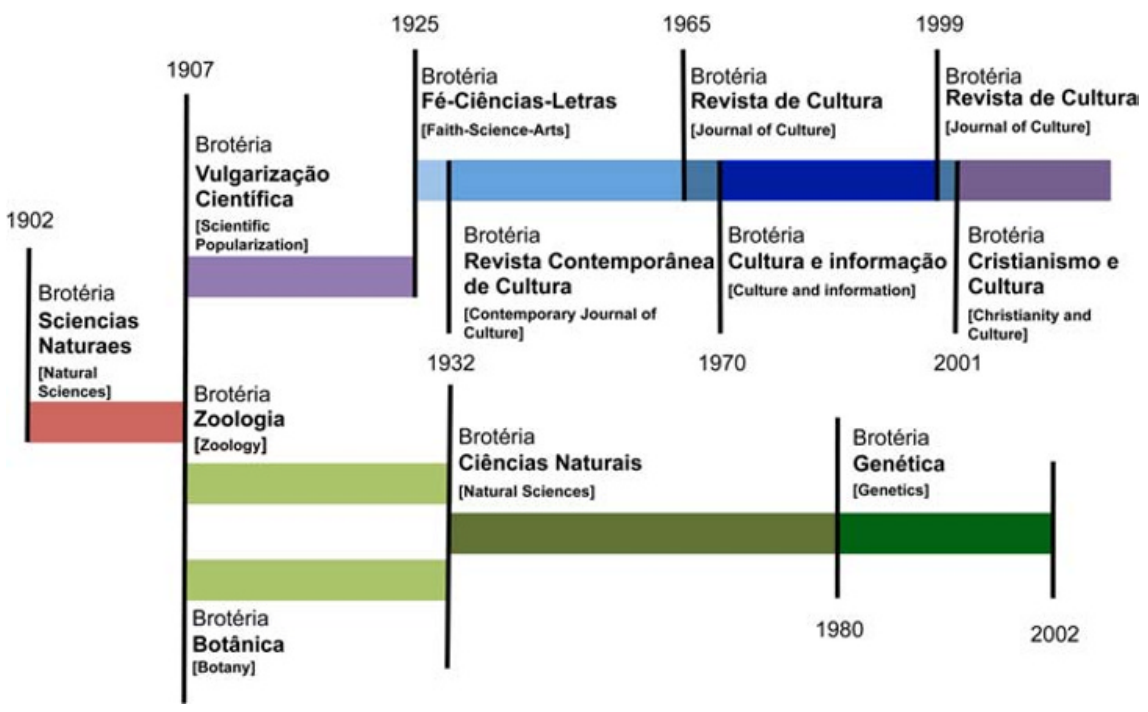

FIGURE 12.3 Editorial evolution of the journal Brotéria

CREDITS: ADAPTED FROM FÉ, CIÊNCIA, CULTURA: BROTÉRIA-10O ANOS, EDITED BY HERMÍNIO RICO, S.J., AND JOSÉ EDUARDO FRANCO (LISBON: GRADIVA, 2003), 101

and geophysics. ${ }^{38}$ Although it shared certain similarities with Brotéria, like the Portuguese Vulgarização científica, the journal was primarily aimed at a popular, non-specialist readership, and hence differed from Brotéria's research series Botânica and Zoologia.

In 1925, Silva Tavares broadened the aims of the Vulgarização científica by transforming it into a cultural, philosophical, and humanistic periodical which still exists and continues to be edited by the Portuguese Jesuits today (Figure 12.3). This so-called "cultural" Brotéria, which was published alongside the "scientific" Brotéria series, was consistently regarded as a high-quality journal, especially for its articles on philosophy, theology, and history, which were written by some of the most learned Portuguese Jesuits of the twentieth century such as Manuel Antunes (1918-85), António Leite (1911-2004), Domingos

38 On the history of Observatorio del Ebro and the journal Ibérica see Josep Battló and David Altadill, "The Ebre Observatory-Its Path to Ionospheric Research," Advances in Space Research 39, no. 5 (2007): 941-46; Nestor Herran, "Science to the Glory of God': The Popular Science Magazine Ibérica and Its Coverage of Radioactivity," Science and Education 21 (2012): 335-53; Pascual Bolufer, "Science and Technology in the 2oth Century as Seen through the Journal Ibérica (1914-2003)," Contributions to Science 7, no. 2 (2011): 185-90; Maria Genescà-Sitjes, "Ibérica magazine (1913-2004) and the Ebro Observatory," Contributions to Science 9 (2013): 159-68. 
Maurício (1896-1978), and João Pereira Gomes (1917-2002). ${ }^{39}$ Given the diversity of the subjects it covered, and its apologetic program, the cultural Brotéria, unlike the scientific Brotéria, is comparable to the other learned magazines the Society of Jesus published such as Razón y fé, Études, La Civiltà Cattolica, Stimmen der Zeit, Przeglad Powszechny (Poland, 1883), Studies (Ireland, 1902), Aggiornamenti sociali (Italy, 1950), Mensaje (Chile, 1951), and Choisir (Switzerland, 1959).

\section{Brotéria and Portuguese Science during the Early Years of Estado Novo (1932-57)}

After Silva Tavares's death in 1931, Luisier took over the editorship of Brotéria and merged the two scientific series—Botânica and Zoologia —into a unique scientific magazine entitled Brotéria-Ciências naturais. Although he viewed this measure as a temporary one, in practice the unified journal continued to be published until 1980 (Figure 12.3)..$^{40}$ As in previous years, Brotéria-Ciências naturais published research papers on zoology and botany, but it also began to publish research by Portuguese scientists working at public laboratories and scientific institutes, such as the National Agronomic Station (Lisbon), the Botanical Institute of the Faculty of Sciences (Lisbon), and the Botanical Institute Dr Gonçalo Sampaio (Porto). ${ }^{41}$ Thus, a Jesuit periodical became one of the leading channels for the publication of Portuguese biological research.

The interaction between the researchers of the Botanical Institute of Lisbon and Brotéria began in the early 1940s. The first issue of BrotériaCiências naturais, published in February 1942, contained one of five articles in a series by Carlos Neves Tavares (1914-72) describing "novel or interesting" species of lichens collected on Portuguese mountains. ${ }^{42}$ Similarly, the second

39 On the appraisal of the cultural Brotéria see Hermínio Rico, S.J., and José Eduardo Franco, eds., Fé, ciência, cultura: Brotéria—10o anos (Lisbon: Gradiva, 2003). For critical editions of the work of Manuel Antunes and João Pereira Gomes see respectively: José Eduardo Franco, ed., Obra completa do Padre Manuel Antunes (Lisbon: Fundação Calouste Gulbenkian, 2007-12), which comprises fourteen volumes, and Henrique Leitão and José Eduardo Franco, eds., Jesuítas, ciência e cultura em Portugal: Obra selecta do Pe. João Pereira Gomes SJ (Lisbon: Esfera do Caos, 2012).

Afonso Luisier, S.J., "Prólogo," Brotéria-Ciências naturais 1 (1932): 7-8.

41 For more details on the scientific history of Brotéria under the direction of Luisier see Romeiras, "Das ciências naturais à genética," 271-87.

42 He collected lichens on Serra de Sintra, Serra da Estrela, Serra da Lousã, Serra do Gerês, Serra de Monchique, and Serra do Buçaco. Carlos das Neves Tavares, "Notas liquenológicas," Brotéria-Ciências naturais 11 (1942): 42-48. In the following years, Tavares continued publishing his research on lichens in Brotéria: Carlos das Neves Tavares, "Líquenes da Serra da Estrela (contribuição para o seu estudo)," Brotéria-Ciências naturais 14 (1945): 
issue, published in 1942, contained work by another member of this institute, the promising botanist and geneticist Flávio Resende (1907-67), which had been produced in cooperation with Karl von Poellnitz (1896-1945) and described novel varieties of the succulent plant Haworthia tessellata. ${ }^{43}$

The most prolific authors based at the Porto Botanical Institute whose articles appeared in Brotéria-Ciências naturais included Manuel Cabral Resende Pinto (1911-9o), Arnaldo Rozeira (1912-84), and Joaquim Sampaio (1899-c.1965), son of the renowned botanist Gonçalo Sampaio. Resende Pinto was a prominent mycologist who had published several articles on Portuguese fungi in Brotéria, and his detailed catalog on Hymenomycetes, published in BrotériaCiências naturais between 1942 and 1945, became one of his most significant taxonomic works. ${ }^{44}$ Rozeira, meanwhile, had published two of his most important works of the 1940 in Brotéria, including his 1943 article identifying 151 new or little-known plants of the flora of northern Portugal and which also described a new botanical species, Saxifraga sampaioi. ${ }^{45}$ In 1949, Brotéria published Rozeira's dissertation presented in the tender for professor of botany in the Faculty of Sciences (Porto). ${ }^{46}$ The publication of this large monograph, unusual for a scientific periodical, testifies to the close cooperation between Brotéria and Porto's academic community. Joaquim Sampaio wrote several articles on the identification and classification of blue and green algae, having described some new species of the Portuguese flora ${ }^{47}$ Besides being an active

14-25, 49-61; Tavares, "Notas lichénologiques," Brotéria-Ciências naturais 16 (1947): 145-57; Tavares, "Nótulas de fanerogamia Portuguesa," Brotéria-Ciências naturais 28 (1959): 69-75.

43 Flávio Resende and Karl von Poellnitz, "Suculentas africanas: Variedades novas de Haworthia tessellata Haw," Brotéria-Ciências naturais 11 (1942): 49-55.

44 Manuel Cabral Resende Pinto, "Hymeniales de Portugal," Brotéria-Ciências naturais 11 (1942): 5-20; 62-80; 106-36; 153-76; Pinto, "Hymeniales de Portugal," Brotéria-Ciências naturais 12 (1943): 5-20; 58-75; 116-27;180-90; Pinto, "Hymeniales de Portugal:Hydnaceae," Brotéria-Ciências naturais 13 (1944): 25-36; Pinto, "Hymeniales de Portugal: Polyporaceae," Brotéria —Ciências naturais 13 (1944): 30-36; 131-40; Pinto, "Hymeniales de Portugal," Brotéria-Ciências naturais 14 (1945): 26-42. On a more detailed description of this catalog, see Romeiras, "Das ciências naturais à genética," 282.

45 Saxifraga sampaioi was named in homage to Gonçalo Sampaio, his former teacher, and the patron of the Botanical Institute. Arnaldo Rozeira, "Plantas novas ou pouco citadas para Trás-os-Montes e Alto-Douro," Brotéria-Ciências naturais 12 (1943): 145-71.

46 Arnaldo Rozeira, "A secção stoechas gingins, do género Lavandula Linn," BrotériaCiências naturais 18 (1949): 5-84.

47 Joaquim Sampaio, "Sinopse das Desmídias conhecidas na flora portuguesa," BrotériaCiências naturais 12 (1943): 97-115; Sampaio, "Sinospe das Desmídias conhecidas na flora portuguesa," Brotéria-Ciências naturais 13 (1944): 6-24; 88-130; Sampaio, "Sinospe das 
taxonomist, Sampaio became particularly interested in the history of botany and published three articles in Brotéria focusing on the taxonomic work of renowned Portuguese botanists. ${ }^{48}$

One of the most interesting cases in the vast collaborative network between Broteria and other Portuguese scientific institutions was the journal's collaboration with the National Agronomic Station. This public institute, founded in 1936, played a crucial role in the development of cytogenetics and plant breeding in Portugal during the political regime of "Estado Novo" (1933-74). Under Luisier's editorship of Brotéria, a group of geneticists led by António Sousa da Câmara (1901-71), the head of the National Agronomic Station, published several papers on plant genetics, ${ }^{49}$ with the collaboration starting in 1939, only three years after the official establishment of the National Agronomic Station. In that year, Sousa da Câmara published his first paper in Brotéria on the fragmentation of chromosomes caused by X-rays, ${ }^{50}$ and in the years that followed other work by researchers from the Department of Cytology and Cytogenetics, especially on genetics and plant breeding, also appeared in the journal (Figure 12.4).

After the death of its first editor, Brotéria extended its scientific program and started to publish papers on subjects such as the history of botany, physiology, plant breeding, and genetics, and played a crucial role in the development of Portuguese science. The journal, which received financial support from the Portuguese government from 1930 onwards, contributed to the diffusion of the scientific work of some of the most prominent Portuguese biologists and also

Desmídias conhecidas na flora portuguesa," Brotéria-Ciências naturais 14 (1945): 128-48; Sampaio, "Cianófitas da Serra da Estrela," Brotéria-Ciências naturais 16 (1947): 105-13; Sampaio, "As algas marinhas portuguesas e a extracção do iodo," Brotéria-Ciências naturais 16 (1947): 165-72; Sampaio, "Uma localidade nova para o Ascophyllum nodosum Le Jol., descoberta pelo Prof. G. Sampaio," Brotéria-Ciências naturais 17 (1948): 56-58.

48 Joaquim Sampaio, "Subsídios para a história da botânica em Portugal. I — O colector Isaac Newton e o estudo das criptogâmicas celulares portuguesas," Brotéria-Ciências naturais 15 (1946): 20-52; Sampaio, "Subsídios para a história da botânica em Portugal. II-O Dr. Romualdo Fragoso, o Dr. Gonçalo Sampaio e a micologia portuguesa," BrotériaCiências naturais 17 (1948): 115-32; Sampaio, "Subsídios para a história da botânica em Portugal. II - O Dr. Romualdo Fragoso, o Dr. Gonçalo Sampaio e a micologia Portuguesa," Brotéria-Ciências naturais 18 (1948): 86-92; 97-108.

49 On António Sousa da Câmara and the National Agronomic Station see Tiago Saraiva, "Laboratories and Landscapes: The Fascist New State and the Colonization of Portugal and Mozambique," HoST:Journal for the History of Science and Technology 3 (2009): 7-39; Saraiva, "Fascist Labscapes: Genetics, Wheat and the Landscapes of Fascism in Italy and Portugal," Historical Studies in the Natural Sciences 40 (2010): 457-98.

50 António Sousa da Câmara, "Fragmentos cromosómicos produzidos pelos raios X," Brotéria-Ciências naturais 8 (1939): 166-79. 


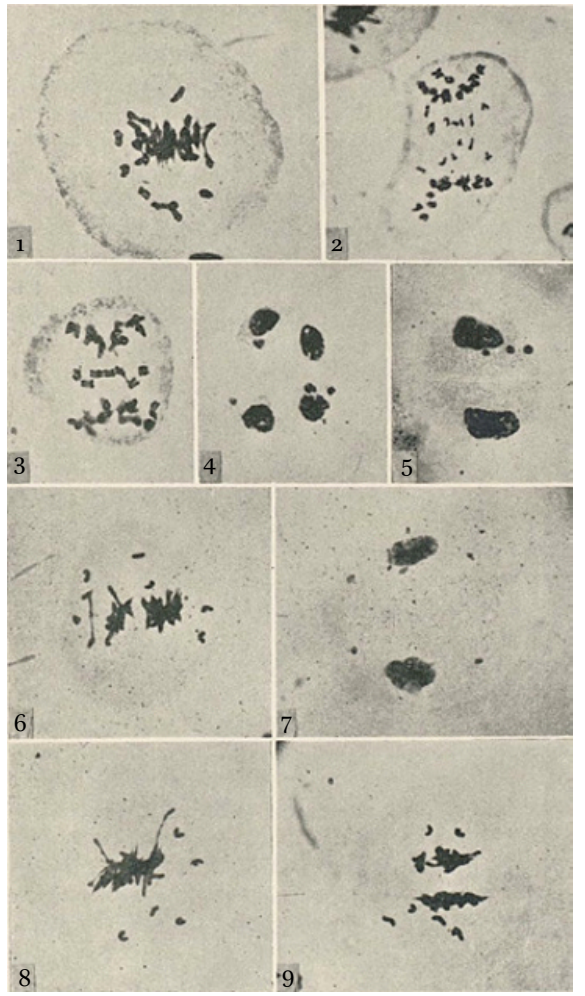

FIGURE 12.4

Microscopic observation on the movement of univalent chromosomes on wheat pentaploid hybrids

CREDITS: ADAPTED FROM BROTÉRIACIÊNCIAS NATURAIS 19 (1950): 180-187 [STAMP INSERTED BETWEEN PAGES 184 AND 185]. ARCHIVES OF THE JOURNAL BROTÉRIA

to the development of genetics and plant breeding, which was one of the major research priorities in the early years of the Estado Novo. By publishing papers written by scientists based at state laboratories, Brotéria renewed its importance as a scientific publication and served to reinforce the scientific credibility of the Jesuits during this period.

\section{Luís Archer and the Emergence of Molecular Genetics}

After Luisier's death in 1957, the journal's previous editorial policy was maintained by the new director of Brotéria, the Jesuit José Vilhena de Carvalhaes (1912-2008), who was in charge for a relatively brief period of time (1957-61). This changed under the direction of Luís Archer (1926-2011), who took over the editorship in 1961. In the final issue of that year, the journal published its firstever article on biochemistry, ${ }^{51}$ a subject which would be covered extensively in

51 William Sullivan, S.J., and James. V. Boyle, "The Effect of X-Radiation on the Succinic Dehydrogenase Activity on the Dividing Stages of Tetrahymena pyriformis GL.," BrotériaCiências naturais 30 (1961): 77-82. On the history of biochemistry in Portugal, see Isabel Amaral, A emergência da bioquímica em Portugal: As escolas de investigação de Marck 
Brotéria from the early 1960s onwards, with research on cellular metabolism, enzymology, and protein electrophoresis. ${ }^{52}$ Between 1965 and 1969 , longer editions of Brotéria were published featuring the doctoral dissertations of three promising Portuguese biologists-Francisco Guerra (1932-), Luís Archer, and Roberto Salema (1932-) — on mitochondrial tumefaction, DNA-mediated transformation in bacteria, biogenesis, and the structure of starch. ${ }^{53}$ By this stage, Brotéria had become a modern biological journal, one which played an important role in disseminating new biochemistry research both in Portugal and abroad.

Yet, important changes lay ahead. In the 1970s, under Archer's leadership, Brotéria published the first papers on molecular genetics to appear in a Portuguese journal. As the number of Portuguese molecular geneticists was still extremely small, most of these papers were written by foreign researchers. ${ }^{4}$ The substitution of taxonomy for biochemistry and molecular genetics was carried out by Archer who, as the first Portuguese molecular geneticist, was particularly keen on modernizing Brotéria and transforming the journal into one of the vectors for the promotion of molecular biology at an academic level..$^{55}$ In 1980, following the rapid growth of research in genetics, Archer once again redefined the editorial program of Brotéria and, with financial support from the Portuguese Society of Genetics, created Brotéria-Genética, the first national scientific journal entirely dedicated to this new science. ${ }^{56}$ As with Silva Tavares and Luisier before him, Archer combined his own scientific interests with the editorial program of Brotéria, thus fulfilling the need for a specialized journal on genetics in Portugal (Figure 12.5). ${ }^{57}$

Athias e de Kurt Jacobsohn (Lisbon: Fundação Calouste Gulbenkian and Fundação para a Ciência e Tecnologia, 2006).

$5^{2}$ For a list of the most important biochemistry articles published in this period, see Romeiras, "Das ciências naturais à genética," 288n818 and 30on854.

Francisco Carvalho Guerra, "Tumefacção mitocondrial: Estudo comparativo das mitocôndrias do cérebro e do fígado," Brotéria-Ciências naturais 34 (1965): 3-226; Luís Archer, S.J., "DNA-Mediated Transformation," Brotéria-Ciências naturais 36 (1967): 107-76; Roberto Salema, "Amido: Estudo ultrastrutural da sua biogénese em plantas superiores," Brotéria-Ciências naturais 38 (1969): 1-127.

54 For a list of the most relevant international articles on molecular genetics see Romeiras, "Das ciências naturais à genética," 301n857.

55 On Luís Archer and the history of molecular biology in Portugal, see Francisco Malta Romeiras, "The Emergence of Molecular Genetics in Portugal: The Enterprise of Luís Archer S.J. (1926-2011)," Archivum historicum Societatis Iesu 82, no. 164 (2013): 501-12.

56 Miguel Mota, "A contribuição da Brotéria para o desenvolvimento da genética," in Rico and Franco, Fé, ciência, cultura: Brotéria-10o anos, 517-27.

From 1980 to 2002, and under Archer's direction, Brotéria - Genética published more than three hundred original articles on genetics and bioethics. For a complete list of those 


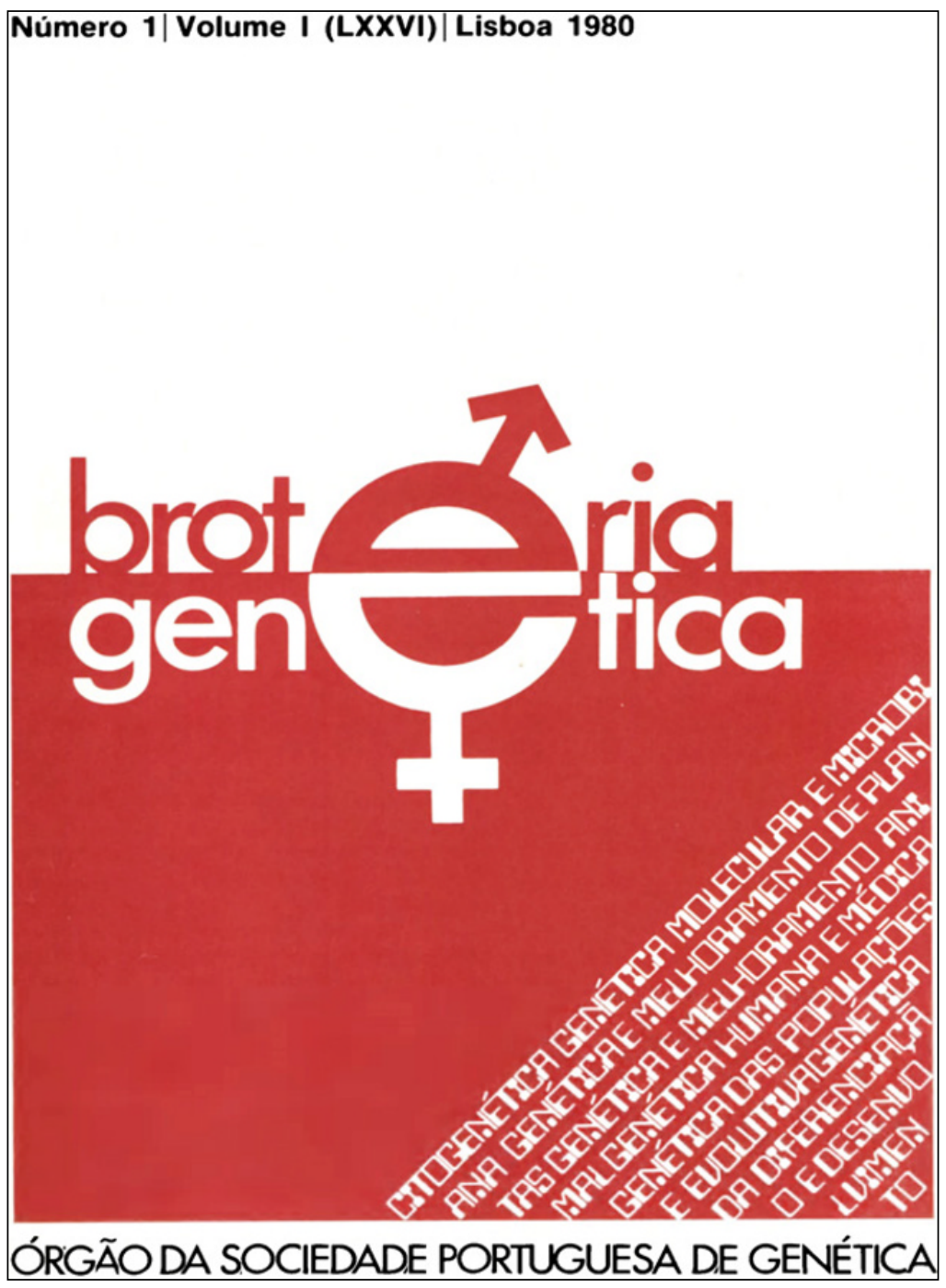

FIGURE 12.5 Cover of the first issue of the journal Brotéria-Genética (1980) CREDITS: ARCHIVES OF THE JOURNAL BROTÉRIA

articles, see Indíces gerais da Brotéria Científica (1902-2002) (Braga: Brotéria Genética, 2002). The most important statistical data are presented and discussed in Romeiras, "Das ciências naturais à genética," 301-2. Luís Archer directed Brotéria-Ciências naturais from 1962 to 1979 and Brotéria-Genética from 1980 to 2002. He was also the editor of the cultural journal Brotéria-Cultura e informação from 1972 to 1975 and from 1993 to 2000. 
Besides publishing articles by non-Portuguese researchers, Brotéria-Genética also helped disseminate the work of some of Portugal's most prominent geneticists on bacterial genetics, animal and plant breeding, and human genetics. ${ }^{58}$ Most of the articles on bacterial genetics were written by members of the Laboratory of Molecular Genetics of the Instituto Gulbenkian de Ciência, founded and directed by Archer himself in the period from 1971 to $1991 .^{59}$ As editor of Brotéria-Genética and head of this institute, he promoted research in his field of expertise while at the same time providing an outlet for the publication of the most important research of his peers. Thus, if the publication of articles on plant and animal breeding represented continuity with the editorial program of Brotéria-Ciências naturais, the appearance of works on human genetics was one of the key editorial innovations of Brotéria-Genética. ${ }^{60}$ These articles focused on the pathology, incidence, and diagnosis of severe monogenic diseases and of chromosomal disorders, such as cystic fibrosis, sickle-cell anemia, and Down syndrome. ${ }^{61}$ By publishing research data from Portuguese patients, Brotéria - Genética began to assume clinical relevance for the first time.

Brotéria, the Laboratory of Molecular Genetics, and the Portuguese Society of Genetics, which Archer directed from 1978 to 1981, were not only interconnected but were also co-dependent, since the public image of each of these entities relied heavily on the public image of their counterparts. It must be noted that, despite being the official journal of an academic society, the Portuguese Society of Genetics, Brotéria-Genética was headed by a Jesuit and belonged to the Society of Jesus. One century after its foundation by a group of Jesuit teachers, Brotéria had acquired a prominent status in Portuguese science, and some of the members of the Society of Jesus were among Portugal's most respected scientists.

58 Like in the previous years, Brotéria continued to be an active and important journal for Portuguese scientists, publishing not only original research articles but also review articles from some of the most prominent geneticists such as Abílio Fernandes (1906-94), José Antunes Serra (1914-90), Dom Miguel Pereira Coutinho (1915-98), Miguel Noronha Wagner (1922-91), Miguel Mota (1922-), Tristão de Melo Sampaio (1923-98), Amândio Sampaio Tavares (1928-), Helena Paveia (1945-2009), Henrique Guedes Pinto, Jorge Antunes Correia, Hermínia Lencastre, and José Rueff Tavares (1954-).

Romeiras, "Das ciências naturais à genética," 302-4.

6o For a list of the most relevant articles on animal and plant breeding, see Romeiras, "Das ciências naturais à genética," 304-5n863.

For a list of the most relevant articles on human genetics, see ibid., $305 \mathrm{n} 864$. 


\section{Conclusion}

Brotéria's modest foundation as a taxonomical journal by a small group of teachers in a Jesuit college in a sleepy provincial town belies its remarkable history. Brotéria's trajectory coincides with the development of botany, zoology, molecular biology, and genetics in Portugal, and it is beyond question that the journal played a major role in that story. Indeed, today, historians of science view Brotéria as one of the most important scientific periodicals to have been published in Portugal during the twentieth century.

But the importance of Brotéria transcends its national boundaries. Unlike other contemporary Jesuit journals, Brotéria was not a cultural periodical in the wide sense. It was not even a religious or apologetic magazine with a scientific section. Brotéria was strictly and programmatically a scientific journal. It was initially created with the aim of contributing to the identification, description, and classification of new botanical and zoological species, and gradually expanded its scope to the modern subjects of biochemistry and molecular genetics. The strictly scientific purpose behind its foundation, its unusual longevity, the extensive taxonomical work it published, as well as the role it played in the foundation and development of new research fields in Portugal, such as biochemistry and molecular genetics, and its editorial flexibility are among Brotéria's most important distinctive features, both in the Jesuit context and in the broader history of scientific periodicals. By reflecting the scientific interests of each of its directors, and by closely accompanying the emergence and development of some of the major research topics in twentieth-century biology, Brotéria continually justified its existence as a scientific journal. Less obvious but surely not less important, the centennial existence of Brotéria and its distinctive nature point to a versatility and resilience common to other Jesuit enterprises in the twentieth century. 